\title{
Occupational chemical burns: a 2-year experience in the emergency department
}

This article was published in the following Dove Press journal:

Journal of Multidisciplinary Healthcare

30 September 2011

Number of times this article has been viewed

\section{Panagiotis Touzopoulos' \\ Paul Zarogoulidis ${ }^{2}$ \\ Alexandros Mitrakas' \\ Michael Karanikas' \\ Panagiotis Milothridis' \\ Dimitrios Matthaios' \\ loannis Kouroumichakis ${ }^{3}$ \\ Stella Proikaki ${ }^{3}$ \\ Paschalis Pavlioglou ${ }^{3}$ \\ Nikolaos Katsikogiannis ${ }^{4}$ \\ Theodoros C Constantinidis ${ }^{5}$ \\ 'Ist University Surgical Department, University General Hospital of \\ Alexandroupolis, Democritus \\ University of Thrace, Alexandroupolis, \\ ${ }^{2}$ Pulmonary Department, University \\ General Hospital of Alexandroupolis, \\ Democritus University of Thrace, \\ Alexandroupolis, ${ }^{3} 2$ nd Internal \\ Medicine Department, University \\ General Hospital of Alexandroupolis, \\ Democritus University of Thrace, \\ Alexandroupolis, ${ }^{4}$ Surgical \\ Department (NHS), University \\ General Hospital of Alexandroupolis, \\ ${ }^{5}$ Medical School, Laboratory of \\ Hygiene and Environmental Protection, \\ Democritus University of Thrace, \\ Regional Laboratory of Public Health \\ (Eastern Macedonia-Thrace), Greece}

Correspondence: Paul Zarogoulidis Pulmonary Department, University General Hospital of Alexandroupolis, Democritus University of Thrace, Alexandroupolis, Greece

Tel +30 697727 I974

Fax +30 23I 0992433

Email pzarog@hotmail.com

\begin{abstract}
Chemical burn injuries are a result of exposure to acid, alkali, or organic compounds. In this retrospective study, a total of 21 patients suffering occupational chemical burns, came to the emergency room at the University General Hospital of Alexandroupolis, from 2008 to $2010 ; 76.2 \%$ were workers, $19 \%$ were farmers, and $4.8 \%$ were desk officers. The majority of burns were due to exposure to acid (61.9\%). Upper extremities were the most frequently injured area followed by the lower extremities and thorax. None of the patients needed further hospital care, but in the follow-up, four of the patients suffered keloid. Proper surgical treatment at the emergency room decreases the length of hospital stay for patients who suffer chemically induced burns.
\end{abstract}

Keywords: chemical burns, surgical treatment, labor accidents

\section{Introduction}

Chemical burn injuries are a result of exposure to acid, alkali, or organic compounds. ${ }^{1}$ Carelessness is the most common cause of chemical burns, and caution is the most effective form of prevention. ${ }^{2}$ To avoid occupational exposure, proper safety precautions should be taken by employees when working with hazardous materials. Employers must provide them with adequate training and protective equipment. Injury as a result of a chemical burn has greater potential for progressive tissue damage than other types of burn injuries. ${ }^{3}$ Chemical burns are less common than others, ${ }^{4}$ and their etiology differs depending on population, geography, presence of industry, social status, and education. ${ }^{46}$

The exact symptoms of a chemical burn depend on the chemical involved. Symptoms include itching, bleaching or darkening of skin, burning sensations, trouble breathing, coughing blood, and/or tissue necrosis. Common sources of chemical burns include sulfuric acid $\left(\mathrm{H}_{2} \mathrm{SO}_{4}\right)$, hydrochloric acid $(\mathrm{HCl})$, lye $(\mathrm{NaOH})$, lime $(\mathrm{CaO})$, and silver nitrate $\left(\mathrm{AgNO}_{3}\right)$. Chemical burns may occur through direct contact with body surfaces including skin and eyes, inhalation, and ingestion. Lipophilic substances that diffuse efficiently in human tissue, eg, hydrofluoric acid, sulfur mustard, and dimethyl-sulfate, may not react immediately, but produce the burns and inflammation hours after the contact. Chemical fabrication, mining, medicine, and related professional fields are examples of occupations where chemical burns may occur.

Prompt wound irrigation is the most critical aspect in preventing the extent of dermal burns from exposure to caustic substances. A burn center case series found that patients who received irrigation within 10 minutes had a 5 -fold decrease in full-thickness injury and a 2-fold decrease in length of hospital stay. ${ }^{7}$ The key treatment to that kind of burn begins in the emergency room. The first priority is to ensure complete removal 
of the offending agent. If a question of airway compromise exists, the airway must be secured. Adequate irrigation is difficult to define and depends on the amount of exposure and the agent involved. Using litmus paper to measure the $\mathrm{pH}$ of the affected area or the irrigating solution is helpful. Complete removal and neutralization of concentrated acids and alkalis may require several hours of irrigation. Tap water is adequate for irrigation. Low-pressure irrigation is desired; high pressures may exacerbate the tissue injury. ${ }^{7-10}$ After initial decontamination, the full extent of the injury must be ascertained and the patient must be treated as a typical burn patient. Based on the degree of injury, adequate fluid resuscitation must be ensured and precautions should be taken to prevent complications (eg, hypothermia, infection, rhabdomyolysis). Burns to the hands, face, or perineum may require appropriate specialties. Ophthalmologic consultation is recommended for patients with ocular burns from acids or bases, if there is any significant degree of corneal or scleral injury. Caustic ingestions may require multiple specialties, including gastroenterology and otolaryngology. Medications have a limited role in the treatment of most chemical burns. Topical antibiotic therapy is usually recommended for dermal and ocular burns. Pain medications are important for subsequent burn care. There has been some use of aloe products on mild burns; however, currently, no definitive information on their use for chemical burns is available. ${ }^{11}$

In this retrospective study, we report our center's experience in the emergency room.

\section{Methods}

We recorded all cases that came to the emergency room of Alexandroupolis complaining of chemical burns due to chemical substances during work time in 2008-2010. We recorded their age, their job, and the kind of chemical substance that caused the burn. During the clinical examination we took care of the total surface of the burn, the anatomical site, and the depth of the burn. We were concerned about therapy as well as the recovery of the affected areas. The study was authorized by the Investigational Review Board of our hospital.

\section{Results}

In the emergency room, 21 patients with chemically induced burns due to occupational exposure were admitted between 2008 and 2010. This number represents about $61.8 \%$ of all chemical burns, since 13 more presented with chemical burns caused by chemical substances in their home. Sixteen patients $(76.2 \%)$ worked in industrial areas, four patients $(4 \%)$ were farmers, and one (4.8\%) had a desk job (Table 1). All patients
Table I Burns and occupations

\begin{tabular}{lll}
\hline & Number & $\%$ \\
\hline Workers & 16 & $76.2 \%$ \\
Farmers & 4 & $19 \%$ \\
Desk officers & 1 & $4.8 \%$ \\
Businessmen & 0 & 0 \\
\hline
\end{tabular}

had been working more than 10 years, and the median of their age was 52 years (38-65). The majority of the chemical burns were due to exposure to: (a) acid $(61.9 \%)$, (b) to alkali (19.05\%), and (c) to unknown substances (19.05\%) (Table 2). The most common sites of exposure were the upper limbs, followed by lower limbs and the chest (Table 3). All burns were of second degree. All burns were treated conservatively, by water treatment at the site of injury, local and systemic antimicrobial therapy, analgesia, covering the burn site, and re-evaluation after 3 days. No patients were admitted to the clinic, because burn surfaces were very small. Four patients had facial burns and five at the lateral surface of the neck, with no evidence of respiratory burn, while none of them needed intubation. All dermal burns were rechecked every 3 days during the first 2 weeks and then once a week for 2 months. At the time of re-evaluation, four of the patients needed cosmetic surgery due to keloids, two on the upper extremities, one on the chest, and one on the earlobe.

\section{Discussion}

Chemical burns can be caused by acids or bases that come into contact with tissue. ${ }^{1}$ Both acids and bases can be defined as caustics, which cause significant tissue damage on contact. Most acids produce a coagulation necrosis by denaturing proteins, forming a coagulum (eg, eschar) that limits the penetration of the acid. Bases typically produce a more severe injury known as liquefaction necrosis. This involves denaturing of proteins as well as saponification of fats, which does not limit tissue penetration. Hydrofluoric acid differs from other acids because it induces liquefaction necrosis. The severity of the burn is related to a number of factors, including the $\mathrm{pH}$ of the agent, the concentration of the agent, the length of the contact time, the volume of the offending agent, and the physical form of the agent. The ingestion of solid pellets of alkaline substances results in prolonged contact time

Table 2 Kind of chemical

\begin{tabular}{lll}
\hline & Number & $\%$ \\
\hline Acid & 13 & $61.9 \%$ \\
Alkali & 4 & $19.1 \%$ \\
Unidentified & 4 & $19.1 \%$ \\
\hline
\end{tabular}


Table 3 Anatomical area injured

\begin{tabular}{lll}
\hline & Number & $\%$ \\
\hline Face & 4 & $19 \%$ \\
Neck & 5 & $23.8 \%$ \\
Thorax & 8 & $38.1 \%$ \\
Abdomen & 3 & $14.3 \%$ \\
Back & 3 & $14.3 \%$ \\
Upper extremities & 16 & $76.2 \%$ \\
Lower extremities & 7 & $33.3 \%$ \\
Hand & 14 & $66.7 \%$ \\
Foot & 3 & $14.3 \%$ \\
Perineum & 0 & 0 \\
\hline
\end{tabular}

in the stomach, and thus more severe burns. In addition, concentrated forms of some acids and bases generate significant heat when diluted or neutralized, resulting in thermal and caustic injury. The long-term effect of caustic dermal burns is scarring and, depending on the site of the burn, scarring can be significant. Ocular burns can result in opacification of the cornea and complete loss of vision. Esophageal and gastric burns can result in stricture formation.

These kinds of burns are less common than the others. ${ }^{4}$ Their etiology differs depending on population, geography, presence of industry, social status, and education..$^{4-6}$ According to literature, most burns $(4 \%-13 \%)$ are due to criminal acts. ${ }^{12,13}$ An occupational chemical injury is hazardous, ${ }^{14,15}$ not only because of the inherent danger of the toxic materials, but also because of the problems posed by the physical management of these agents. ${ }^{16}$

Chemical burns are common in the lower socioeconomic classes (workers/farmers) and initial basic treatment does not always prevent further tissue damage. An important factor seems to be carelessness due to neglecting safety rules. Despite this, the knowledge of some hygiene rules protected workers from severe degree chemical burns, due to the fact that all of them cleared the traumatized area with plenty of water at the time of injury. Chemical substances traumatize tissues ${ }^{17}$ by destroying proteins with different mechanisms such as degradation, oxidation, and dehydration. Therefore instant clearing of the burn area with water lowers trauma depth, and morbidity. ${ }^{18}$

The most common chemical substance is acid, which is commonly used in agriculture, industry, and general occupational use. The correct treatment of a chemical burn depends on recognition of the chemical substance. ${ }^{5}$ This recognition is not always possible, and the immediate therapy for patients in the emergency room is the same for all. This study was conducted in our hospital where there is no special unit for burn injury care, and these cases were treated by the surgical department. Therapy must be individualized for every kind of burn in relation to age, the traumatized area, the kind of chemical substance, the depth of the burn, and the presence of complications. Despite the existence of modern techniques in the treatment of burns, the ability of an experienced surgical team to provide instant surgical care is still ideal. The purpose of this study was to foster the development of special burn units at hospitals in industrial areas, and also knowledge of first aid in the general population.

\section{Conclusion}

A chemical burn can cause more tissue damage than any other type of burn. Working accidents related to chemicals can be very toxic due to the nature of the chemicals, and also due to their method of use. Carelessness is the most common cause of trauma with the upper extremities being the most commonly exposed anatomical area. However, all industries are required to inform employees of any dangerous materials they may encounter in the workplace, and are required to provide adequate training and protective equipment. The strict adherence to safety rules by employees can mean that such trauma is avoided, while good knowledge of first aid results in low morbidity.

\section{Acknowledgments}

All authors contributed equally in the preparation of the manuscript.

\section{Disclosure}

The authors report no conflicts of interest in this work.

\section{References}

1. Barillo DJ, Cancio LC, Goodwin CW. Treatment of white phosphorus and other chemical burn injuries at one burn center over a 51-year period. Burns. 2004;30(5):448-452.

2. Xie Y, Tan Y, Tang S. Epidemiology of 377 patients with chemical burns in Guangdong province. Burns. 2004;30(6):569-572.

3. Curreri PW, Asch MJ, Pruitt BA. The treatment of chemical burns: specialized diagnostic and prognostic considerations. J Trauma. 1970; 10(8):634-642.

4. Singer A, Sagi A, Ben Meir P, Rosenberg L. Chemical burns: our 10-year experience. Burns. 1992;18(3):250-252.

5. Li YY, Liu Y. Analysis of 155 patients with chemical injury: a 5-year experience. Burns. 1993;19(6):516-518.

6. Pitkanen J, Al-Qattan MM. Epidemiology of domestic chemical burns in Saudi Arabia. Burns. 2001;27(4):376-378.

7. Leonard LG, Scheulen JJ, Munster AM. Chemical burns: effect of prompt first aid. J Trauma. 1982;22(5):420-423.

8. Mozingo DW, Smith AA, McManus WF, et al. Chemical burns. J Trauma. 1988;28(5):642-764.

9. Yano K, Hata Y, Matsuka K. Experimental study on alkaline skin injuries - periodic changes in subcutaneous tissue $\mathrm{pH}$ and the effects exerted by washing. Burns. 1993;19(4):320-323.

10. Yano K, Hosokawa K, Kakibuchi M, et al. Effects of washing acid injuries to the skin with water: an experimental study using rats. Burns. 1995;21(7):500-502. 
11. Fulton JA, Hoffman RS. Steroids in second degree caustic burns of the esophagus: a systematic pooled analysis of fifty years of human data: 1956-2006. Clin Toxicol (Phila). 2007;45(4):402-408.

12. Purdue GF, Hunt JL. Adult assault as a mechanism of burn injury. Arch Surg. 1990;125(2):268-269.

13. Yeong EK, Chen MT, Mann R, Lin TW, Engrav LH. Facial mutilation after an assault with chemicals: 15 cases and literature review. J Burn Care Rehabil. 1997;18(3):234-237.

14. Humphris CJ. Chemical danger. Lancet. 2004;364(9449):1937.

15. Simmons JE. Chemical mixtures: challenge for toxicology and risk assessment. Toxicology. 1995;105(2-3):111-119.
16. Saha A, Kumar S, Vasudevan DM. Factors of occupational injury: a survey in a chemical company. Ind Health. 2008;46(2):152-157.

17. Townsend CM Jr, Beauchamp RD, Evers M, Mattox KL, editors. Section III, chapter 22. Sabiston Textbook of Surgery: The Biological Basis of Modern Surgical Practice. 16th ed. Philadelphia, PA: WB Saunders Co; 2007:635-637.

18. Moran KD, O'Reilly T, Munster AM. Chemical burns. A ten-year experience. Am Surg. 1987;53(11):652-653.

\section{Publish your work in this journal}

The Journal of Multidisciplinary Healthcare is an international, peerreviewed open-access journal that aims to represent and publish research in healthcare areas delivered by practitioners of different disciplines. This includes studies and reviews conducted by multidisciplinary teams as well as research which evaluates the results or conduct of such teams or healthcare processes in general. The journal covers a wide range of areas and welcomes submission from practitioners at all levels, from all over the world. The manuscript management system is completely online and includes a very quick and fair peer-review system. Visit http://www.dovepress.com/testimonials.php to read real quotes from published authors.

Submit your manuscript here: http://www.dovepress.com/journal-of-multidisciplinary-healthcare-journal 